\title{
Plasma catalase activity and malondialdehyde level in patients with cataract
}

NA Ateș ${ }^{1}$, Ö Yildirim² ${ }^{2}$ L Tamer $^{3}$, A Ünlü ${ }^{3}$, B Ercan ${ }^{3}$, N Muşlu ${ }^{3}$, A Kanik ${ }^{4}$, R Hatungil ${ }^{5}$ and $U$ Atik $^{3}$

\begin{abstract}
Purpose Oxidative mechanisms play a major role in the aetiology and pathogenesis of cataract, especially in age-related cataract. Our study aims to investigate systemic oxidant and antioxidant markers in cataract patients.

Methods The activity of erythrocyte catalase and the level of malondialdehyde in plasma were measured in 40 patients with cataract and 60 healthy control subjects. The malondialdehyde level, as an index of lipid peroxidation, was determined by thiobarbitüric acid reaction according to Yagi. The determination of catalase activity was measured by a method that was defined by Beutler. Catalase enzyme activity and malondialdehyde level were evaluated to find out whether there was a significant difference in these variables. Analysis of variance was used by forming a general linear model that takes age and gender as the covariate.

Results CAT activity was found to be $13920.2 \pm 847.9 \mathrm{U} / 1$ in cataract patients and $16061.3 \pm 1126.6 \mathrm{U} / 1$ in control subjects. CAT activity in cataract patients was significantly lower than the control subjects $(P=0.008)$. Plasma MDA level is significantly higher in patients with cataract $4.47 \pm 0.35 \mathrm{nmol} / \mathrm{ml}$ compared to the control subjects $2.94 \pm 0.26 \mathrm{nmol} / \mathrm{ml}(P=0.0001)$. There was no significant difference between different cataract subgroups when erythrocyte CAT activities and plasma MDA levels were compared $(P=0.322,0.062)$.

Conclusion This study shows that oxidant/ antioxidant balances alter in the presence of cataract.

Eye (2004) 18, 785-788. doi:10.1038/sj.eye.6700718
\end{abstract}

Keywords: cataract; catalase; malondialdehyde; oxidative stress

\section{Introduction}

As age increases, cataract becomes a more common disorder. Oxidant/antioxidant imbalance plays a key role in ageing. Oxidant/ antioxidant systems imbalance has also proved to have potential importance for ocular tissues. ${ }^{1}$ It seems very likely that oxidative mechanisms play a major role in the aetiology and pathogenesis of cataract formation, especially in age-related cataracts. Lens proteins in particular are subject to extensive oxidative modifications. Some of the protein modifications seen in increased oxidative stress include the formation of mixed disulphides with glutathione, oxidation of cysteine, methionine, and tryptophan, ${ }^{2}$ Oxidative stress has been shown to cause cataracts in invitro models. ${ }^{3}$

Exposure to light may lead to the formation of reactive oxygen species by photo-sensitizing mechanisms. Many tissues slowly regenerate oxidants, causing an increase in the risk for an accumulation of oxidant-inflicted damage in the tissue components. ${ }^{1}$ This is based on the previous findings that exposing lens proteins to ultraviolet light or even sunlight in the presence or absence of aromatic amino acids generates modified proteins. These proteins are insoluble, coloured, and fluorescent. ${ }^{4,5}$ Crystallins and other proteins in lens fibre do not turn over and must serve the lens for the lifetime of the person. Thus, the lens is even more dependent than most tissues on protection from oxidative damage. ${ }^{6}$

The lens, like other tissues, contains a series of defence mechanisms that may protect it from the harmful effects of oxidations. These include superoxide dismutase (SOD), catalase (CAT), and glutathione peroxidase (GPX). Since the lens has a limited capacity for protein turnover, especially in the nucleus, these protective mechanisms have a greater importance in preventing the accumulation of modified proteins. $^{2}$
${ }^{1}$ Department of Medical Biology and Genetics Faculty of Medicine Mersin University Mersin, Turkey

${ }^{2}$ Department of Ophthalmology Mersin University Mersin, Turkey

${ }^{3}$ Department of Biochemistry Mersin University

Mersin, Turkey

${ }^{4}$ Department of Biostatistics Mersin University

Mersin, Turkey

${ }^{5}$ Department of Phsiology Mersin University

Mersin, Turkey

Correspondence: Nurcan Aras Ateş, PhD Mersin Üniversitesi Tıp Fakültesi

Tıbbi Biyoloji ve Genetik Anabilim Dalı Yenişehir Kampüsü

Mersin 33161, Turkey

Tel: + $903243412815 / 1012$

Fax: + 903243412400

GSM: + 905322269903

E-mail: naras@

mersin.edu.tr

Received: 16 April 2003 Accepted: 16 July 2003 
In this study, we aim to investigate the oxidant/ antioxidant balance marker in systemic circulation. For this reason, we determined the plasma malondialdehyde (MDA) level, as the index of lipid peroxidation and erythrocyte catalase (CAT) activity in patients with cataract.

\section{Materials and methods}

\section{Subject}

The study was carried out on 40 subjects with cataract (24 men, 16 women; ages range $43-86$ years), who attended the clinic of the ophthalmology department, and 60 healthy control subjects (30 men, 30 women; age range 45-73 years), who visited our hospital for an annual checkup. The patients with thyroid function disorders, hypertension, diabetes mellitus, liver and renal dysfunction, anaemia, osteoporosis, and inflammatory arthritis were carefully identified and excluded from this study. Patients with cataract formation as a secondary to identifiable causes, such as diabetes, trauma, and steroid administration, were also excluded.

After enrolment, all subjects were given a detailed lens examination to determine the updated cataract status. At the examination, Lens Opacities Classification System II, which uses photographic standards for grading cataract type and severity and was described by Chylack et al, was used to grade lens status with slitlamp examination. The system uses four nuclear standards for grading nuclear opalescence and colour, five cortical standards, and four subcapsular standards. Subjects were qualified as cases if both pupils could be dilated to at least $6 \mathrm{~mm}$ and both eyes had (1) lens opacities of grade 3 and more, and (2) no conditions other than cataract that might account for any vision loss that was present.

Cases were classified into pure (nuclear, cortical, and posterior subcapsular) and mixed types, depending on the lens status of both eyes. Pure cases had a single type of opacity. Patients with more than one type of opacity were classified as mixed.

A subject qualified as a control if (1) both pupils could be dilated to at least $6 \mathrm{~mm}$, (2) both lenses were graded as having no nuclear, posterior subcapsular, cortical opacities or having grade I or II opacities.

Patients were informed about the study and they consented to giving blood samples. Venous peripheral blood samples $(10 \mathrm{ml})$ were collected in ethylenediamine-tetraacetic acid (EDTA)-coated tubes.

\section{The determination of catalase activity}

The determination of CAT activity was measured according to the Beutler method. ${ }^{8}$.

\section{Principle}

Catalase catalyses the breakdown of $\mathrm{H}_{2} \mathrm{O}_{2}$ to $\mathrm{H}_{2} \mathrm{O}$ and $\mathrm{O}_{2}$. The rate of decomposition of $\mathrm{H}_{2} \mathrm{O}_{2}$ by catalase is measured spectrometrically at $230 \mathrm{~nm}$, since $\mathrm{H}_{2} \mathrm{O}_{2}$ absorbs light at this wavelength. Ethanol is added to stabilize the haemolysate by breaking down 'complex II' of catalase and $\mathrm{H}_{2} \mathrm{O}_{2}$. After the addition of $50 \mu \mathrm{l}$ tris buffer, $900 \mu \mathrm{l}$ of $\mathrm{H}_{2} \mathrm{O}_{2}$ and $30 \mu \mathrm{l}$ of $\mathrm{H}_{2} \mathrm{O}$ to the cuvettes, the system is incubated at $37^{\circ} \mathrm{C}$ for $10 \mathrm{~min}$, the haemolysate is added, and, in the following $10 \mathrm{~min}$, the decrease of optical density is measured against blank at $412 \mathrm{~nm}$.

\section{MDA determination}

The MDA levels, as an index of lipid peroxidation, were determined by thiobarbituric acid (TBA) reaction according to Yagi. ${ }^{9}$ The principle of the method depends on the measurement of the pink colour produced by the interaction of TBA with MDA. The sample (for blank $\mathrm{H}_{2} \mathrm{O}$ is used), SDS, acetic acid, thiobarbituric acid, and $\mathrm{H}_{2} \mathrm{O}$ were added to the test tubes, respectively. Then it was incubated at $95^{\circ} \mathrm{C}$ for $30 \mathrm{~min}$ in a water bath. After incubation, butanol-piridine $(15: 1)$ solution is added to the tubes. Than the tubes are centrifugated at 4000 r.p.m. for $10 \mathrm{~min}$. The butanol top layer is measured against blank spectrophotometry at $532 \mathrm{~nm}$ wavelength. 1,1,3,3 tetraetoxypropane was used as the primary standard.

\section{Statistical method}

CAT enzyme activity and MDA level were recorded as averages \pm standard deviation, and it was evaluated whether there was a significant difference. Analysis of variance (ANOVA) was used by forming a general linear model that takes age and gender as the covariate. Statistical tests were performed by SPSS 9.0. A P-value $<0.05$ was considered as statistically significant.

\section{Results}

In all $60 \%$ of the patient group was male and the mean age was $66.5 \pm 1.47,50 \%$ of the control group was male and their mean age was $57.4 \pm 1.0$. All cases in the patient group had bilateral cataract. In total, 18 cataract cases (45.0\%) had cortical cataract, 12 cataract cases $(30.0 \%)$ had mixed type cataract, six cataract cases $(15.0 \%)$ had nuclear cataract and four cataract cases $(10.0 \%)$ had posterior subcapsular cataract.

Erythrocyte CAT activity and plasma MDA level are shown in Table 1. CAT activity was found to be $13920.2 \pm 847.9 \mathrm{U} / 1$ in cataract patients and $16061.3 \pm 1126.6 \mathrm{U} / 1$ in control subjects. CAT activity in cataract patients was significantly lower than the control subjects $(P=0.008)$. 
Table 1 Erythrocyte CAT activitiy and MDA level in patients with cataract and control group

\begin{tabular}{lccc}
\hline Variables & Cataract group & Control group & P \\
& $(\mathrm{n}=40)$ Mean $\pm S E$ & $(\mathrm{n}=60)$ Mean $\pm S E$ & 0.0001 \\
CAT $(\mathrm{U} / \mathrm{l})$ & $13920 \pm 847$ & $16061 \pm 1126$ & 0.008 \\
$\mathrm{MDA}(\mathrm{nmol} / \mathrm{ml})$ & $4.47 \pm 0.35$ & $2.94 \pm 0.26$ & \\
\hline
\end{tabular}

Table 2 Erythrocyte CAT activities and MDA levels in cataract subgroups

\begin{tabular}{|c|c|c|c|c|c|}
\hline Variables & $\begin{array}{c}\text { Cortical cataract } \\
(\mathrm{n}=18) \text { Mean } \pm S E\end{array}$ & $\begin{array}{c}\text { Mixed cataract } \\
(\mathrm{n}=12) \text { Mean } \pm S E\end{array}$ & $\begin{array}{c}\text { Nuclear cataract } \\
(\mathrm{n}=6) \text { Mean } \pm S E\end{array}$ & $\begin{array}{c}\text { Posterior subcapsular } \\
\text { cataract }(\mathrm{n}=4) \text { Mean } \pm S E\end{array}$ & $\mathrm{P}$ \\
\hline CAT $(\mathrm{U} / 1)$ & $14602 \pm 5684$ & $15188 \pm 6223$ & $10385 \pm 4112$ & $12877 \pm 1265$ & 0.322 \\
\hline $\operatorname{MDA}(\mathrm{nmol} / \mathrm{ml})$ & $4.09 \pm 1.32$ & $5.15 \pm 2.74$ & $6.59 \pm 3.86$ & $2.90 \pm 1.57$ & 0.062 \\
\hline
\end{tabular}

The plasma MDA level is significantly higher in patients with cataract $4.47 \pm 0.35 \mathrm{nmol} / \mathrm{ml}$ compared to the control subjects $2.94 \pm 0.26 \mathrm{nmol} / \mathrm{ml}$

$(P=0.0001)$.Erythrocyte CAT activities and plasma MDA levels of four different cataract types are summarized in Table 2. There was no significant difference between the different cataract subgroups when erythrocyte CAT activities and plasma MDA levels were compared $(P=0.322,0.062)$.

\section{Discussion}

Oxygen-free radicals and antioxidant systems are thought to be involved in pathologic processes in the eye, including cataract. ${ }^{10}$ uveitis, $^{11}$ retinopathy of prematurity $^{12}$ corneal inflammation, $^{13}$ and keratitis. ${ }^{14}$ During oxidative stress, a series of highly reactive intermediates are produced, including the superoxide radical $\left(\mathrm{O}_{2}^{-}\right)$, hydrogen peroxide $\left(\mathrm{H}_{2} \mathrm{O}_{2}\right)$, and hydroxy radical $(\mathrm{OH} \cdot)$. These radicals are capable of reacting with proteins, nucleic acids, and lipids leading to lipid, peroxidation of biological membranes. ${ }^{15}$

It is commonly believed that oxidative mechanisms play an important role in the aetiology of cataract, especially maturity-onset cataract. ${ }^{16}$ Oxidative stress has been shown to cause cataract in invitro models. ${ }^{3}$ Many types of cataracts, including maturity-onset cataract, induce extensive oxidative damage to proteins, ${ }^{17}$ lipids $^{18}$ and DNA. ${ }^{19}$

Cataracts have been reported to be associated with elevated level of hydrogen peroxide $\left(\mathrm{H}_{2} \mathrm{O}_{2}\right)$ in the aqueous humor. ${ }^{3}$ Crystallins and other proteins in lens fibre do not turn over and must serve the lens for the lifetime of the person. Thus, the lens is even more dependent than most tissues on protection from oxidative damage. ${ }^{6}$ The lens defence against oxidative damage includes the enzymes GPX, SOD, and CAT.
There is evidence to suggest that GPX and SOD decreases as cataract develops. ${ }^{16,20-22}$

There is also evidence to suggest that low glucose 6phosphate dehydrogenase (G6PD) activity is associated with the increased risk for cataract. Low G6PD activity may lower the supply of reduced nicotinamide-adenine dinucleotide phosphate needed for the protection of reduced glutathione, with reduced nicotinamideadenine dinucleotide phosphate being a cofactor for the enzyme glutathione reductase. ${ }^{16}$

It is shown that the MDA level was increased about two-fold in the plasma and by 1.5 in the lens, in response to selenite treatment in experimental cataract. This shows increased peroxidation of unsaturated fatty acids in the lipid bilayers of lenticular plasma membrane. The peroxidative damage to the lens is one of the major events in the pathogenesis of cataract. The current study proposes that this might be mediated by toxic metabolites of oxygen such as $\mathrm{O}_{2}^{-}, \mathrm{H}_{2} \mathrm{O}_{2}$ and $\mathrm{OH} \cdot$, as a consequence of the impaired enzymatic defences against their toxicity. The same study shows that blood GPX activities were increased and SOD activity was decreased in the selenite-treated group. ${ }^{23}$

In the present study, the plasma MDA level was found to be significantly higher $(P=0.0001)$ and erythrocyte CAT activity was significantly lower in cataract patients compared to the control subjects $(P=0.008)$. But there was no significant difference between cataract subgroups in terms of plasma MDA levels and erythrocyte CAT activities. This may have been due to the low case numbers in cataract subgruops.

In conclusion, this study shows that oxidant/ antioxidant balance changes in cataract. Evaluated in the light of the previous studies on this subject, this study supports the hypothesis of cataract as an oxidative disorder. But further studies are needed to conclude the exact role of the oxidant stress in the development of cataract formation. 


\section{References}

1 Behnding A, Svensson B, Marklund SL, Karlsson K. Superoxide dismutase isoenzymes in the human eye. Invest Ophtalmol Vis Sci 1998; 39: 471-475.

2 Fecondo JV, Augusteyn RC. Superoxide dismutase, catalase and glutathione peroxidase in the human cataractous lens. Exp Eye Res 1983; 36: 15-23.

3 Spector A, Wang GM, Wang RR, Garner WH, Moll H. The prevention of cataract caused by oxidative stress in cultured rat lenses: $\mathrm{I}: \mathrm{H}_{2} \mathrm{O}_{2}$ and photochemically induced cataract. Curr Eye Res 1993; 12: 163-179.

4 Pirie A. Photooxidation of proteins and comparison of photo-oxidised proteins with those of the cataractous human lens. Israel J Med Sci 1972; 8: 1567-1573.

5 Zigman S, Griess G, Yulo T, Schultz J. Ocular protein alterations by near UV light. Exp Eye Res 1973; 15: 255-264.

6 Alberti G, Oguni M, Podgor M, Sperduto RD, Tomarev S, Grassi C et al. Glutathione S-transferase M1 genotype and age-related cataracts. Invest Ophtalmol Vis Sci 1996; 37: 1167-1173.

7 Chylack Jr LT, Leske MC, McCarthy D, Khu P, Kashiwagi T, Sperduto R. Lens opacities classification system II (LOCS II). Arch Ophthalmol 1989; 107: 991-997.

8 Beutler E. Glutathion. In: Beutler E (ed) Red Cell Metabolism: A Manual Of Biochemical Methods. Grune and Stratton: New York 1975; pp 105-107.

9 Yagi K. Lipid peroxides and related radicals in clinical medicine. In: Armstrong D (ed) Free Radicals in Diagnostic Medicine. Plenum Press: New York 1994; pp 1-15.

10 Spector A. Oxidative stress-induced cataract: mechanisms of action. FASEB J 1995, 9: 1173-1182.

11 Gritz DC, Montes C, Atalla LR, Wu GS, Sevanian A, Rao NA. Histochemical localization of superoxide production in experimental autoimmune eveitis. Curr Eye Res 1991; 10: 927-931.
12 Niesman MR, Johnson KA, Penn JS. Therapeutic effect of liposomal superoxide dismutase in an animal model of retinopathy of prematurity. Neurochem Res 1997; 22: 597-605.

13 Alio JL, Ayala MJ, Mulet ME, Artola A, Ruiz JM, Bellot J. Antioxidant therapy in the treatment of experimental acute corneal inflammation. Ophthalmic Res 1995; 27: 136-143.

14 Alio JL, Artola A, Serra A, Ayala MJ, Mulet ME. Effect of topical antioxidant therapy on experimental infectious keratitis. Cornea 1995; 14: 175-179.

15 Hauet TH, Bauza G, Goujan M, Caritez C, Carretier M, Eugene $\mathrm{M}$ et al. Effect of trimetazidine on lipid preoccupation and phosphorus metabolites during cold storage and reperfusion of isolated perfused rat kidneys. Pharmacol Exp Ther 1998; 285: 1061-1067.

16 Jacques PF, Chylack LT, McGandy RB, Hartz SC. Antioxidant status in persons with and senile cataract. Arch Ophthalmol 1988; 106: 337-340.

17 Spector A. The search for a solution to senile cataract. Invest Ophthalmol Vis Sci 1984; 25: 130-146.

18 Babizhaev MA, Deev AI. Free radical oxidation of lipids and thiol groups in formation of a cataract. Biofizika 1986; 31 109-114.

19 Kleiman NJ, Spector A. Quantitation of DNA damage in single human lens epithelial cells. Invest Ophthalmol Vis Sci 1992; 33: 79-99.

20 Feconda JV, Augesteyn RC. Superoxide dismutase, catalase and glutathione peroxidase in human cataractous lens. Exp Eye Res 1983; 36: 15-32.

21 Spector A, Garner WH. Hydrogen peroxide and human cataract. Exp Eye Res 1981; 33: 673-681.

22 Ohrloff C, Hockwin O. Superoxide dismutase (SOD) in normal and cataractous human lenses. Graefes Arch Clin Exp Ophthalmol 1984; 222: 79-81.

23 Orhan H, Marol S, Hepşen IF, Sahin G. Effects of some probable antioxidants on selenite-induced cataract formation and oxidative stress-related parameters in rats. Toxicology 1999; 139: 219-232. 